\title{
Complementary Role of P2 and Adenosine Receptors in ATP Induced-Anti-Apoptotic Effects Against Hypoxic Injury of HUVECs
}

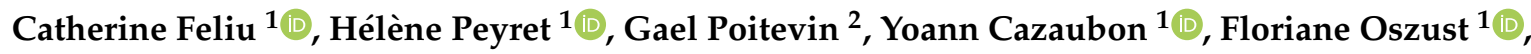 \\ Philippe Nguyen ${ }^{2}$, Hervé Millart ${ }^{1,+}$ and Zoubir Djerada ${ }^{1, *,+}$ \\ 1 Department of Pharmacology, E.A.3801, SFR CAP-santé, Reims University Hospital, 51, rue Cognacq-Jay, \\ 51095 Reims CEDEX, France; catherine.feliu@univ-reims.fr (C.F.); helene.peyret@univ-reims.fr (H.P.); \\ yoann.cazaubon@univ-reims.fr (Y.C.); floriane.oszust@univ-reims.fr (F.O.); \\ herve.millart@univ-reims.fr (H.M.) \\ 2 Laboratory of Hematology, E.A.3801, SFR CAP-santé, Reims University Hospital, 51, rue Cognacq-Jay, \\ 51095 Reims CEDEX, France; gael.poitevin@univ-reims.fr (G.P.); philippe.nguyen@univ-reims.fr (P.N.) \\ * Correspondence: zoubir.djerada@univ-reims.fr; Tel.: +333-26-83-27-82; Fax: +333-26-78-84-56 \\ + These authors contributed to this work equally.
}

Received: 22 February 2019; Accepted: 20 March 2019; Published: 22 March 2019

\begin{abstract}
Background: Vascular endothelial injury during ischemia generates apoptotic cell death and precedes apoptosis of underlying tissues. We aimed at studying the role of extracellular adenosine triphosphate (ATP) on endothelial cells protection against hypoxia injury. Methods: In a hypoxic model on endothelial cells, we quantified the extracellular concentration of ATP and adenosine. The expression of mRNA (ectonucleotidases, adenosine, and P2 receptors) was measured. Apoptosis was evaluated by the expression of cleaved caspase 3. The involvement of P2 and adenosine receptors and signaling pathways was investigated using selective inhibitors. Results: Hypoxic stress induced a significant increase in extracellular ATP and adenosine. After a 2-h hypoxic injury, an increase of cleaved caspase 3 was observed. ATP anti-apoptotic effect was prevented by suramin, pyridoxalphosphate-6-azophenyl-2' $4^{\prime}$-disulfonic acid (PPADS), and CGS15943, as well as by selective A2A, A2B, and A3 receptor antagonists. P2 receptor-mediated anti-apoptotic effect of ATP involved phosphoinositide 3-kinase (PI3K), extracellular signal-regulated kinases (ERK1/2), mitoK ATP, $_{\text {, }}$ and nitric oxide synthase (NOS) pathways whereas adenosine receptor-mediated anti-apoptotic effect involved ERK1/2, protein kinase A (PKA), and NOS. Conclusions: These results suggest a complementary role of P2 and adenosine receptors in ATP-induced protective effects against hypoxia injury of endothelial. This could be considered therapeutic targets to limit the development of ischemic injury of organs such as heart, brain, and kidney.
\end{abstract}

Keywords: endothelial cells; hypoxic stress; purinergic signaling; ATP; adenosine

\section{Introduction}

Vascular endothelium is a cell monolayer at the interface of blood flow and underlying tissues and organs $[1,2]$. Vascular endothelial injury, related to ischemia, generates oxidative stress and apoptotic cell death, which induce a dysfunction and favor the development of atherosclerosis [1-4]. A study describing the time course of apoptosis in different cell types in the heart during ischemia/reperfusion demonstrated that endothelial cells were the first to be affected [5]. Endothelial apoptosis plays a major role in the progression of ischemic injury and radial spread of apoptosis to surrounding cardiomyocytes [4,5]. In another context, endothelial protection has been shown to be essential in maintaining normal cardiac function after transplantation, mainly by controlling coronary 
circulation [6]. Parolari et al. [6] have shown that both myocardial and endothelial protections are necessary to progress from myocardial to cardiac protection. Endothelial injury is presented as the initiator of deleterious cascades of organ damage [7]. Pharmacological protection against vascular endothelial apoptosis could limit the development of ischemic injury of various organs including heart, brain, and kidney.

Many endogenous signaling molecules have been described to induce protection against cardiac stress (hypoxic or ischemic stress). Among them, extracellular nucleotides such as adenosine tri-phosphate (ATP) and nucleosides, such as adenosines, are secreted by endothelial cells and cardiomyocytes during ischemia [8]. Purinergic signaling plays an important role in the cardiovascular system [8,9]. It regulates vascular tone as well as growth of vascular smooth muscle cells and endothelial cells. Purinergic system is involved in vascular remodeling, coagulation, and inflammation [8,10]. It is also implicated in cardiac inotropy and cardioprotection $[8,11]$. Recent studies have established the involvement of P1/P2 receptors in cardioprotection during ischemia [8,12-14].

The nucleotides/nucleosides secreted at high concentration in the interstitium during cardiac ischemia have been reported to be adenosine $5^{\prime}$-triphosphate (ATP) and adenosine $[12,13,15]$. Thus, the purpose of this study was to evaluate the role of ATP and adenosine receptors in endothelial cells during hypoxia-reoxygenation. For this, we confirmed nucleotides/nucleosides release during hypoxia-reoxygenation by an appropriate method able to simultaneously quantify the different targeted compounds in extracellular media. Then, we have studied the induction of cellular protection induced by extracellular signaling of ATP and adenosine as natural agonists. The use of natural agonists is necessary to approach in vivo physio-pathological conditions such as the metabolism and cellular turn-over of nucleotides.

\section{Results}

\subsection{Hypoxic Stress Induces both ATP and Adenosine Release from Endothelial Cells}

The release of adenosine, adenosine $5^{\prime}$-monophosphate (AMP), uridine $5^{\prime}$-monophosphate (UMP), Adenosine $5^{\prime}$-diphosphate (ADP), Uridine $5^{\prime}$-diphosphate (UDP), Adenosine $5^{\prime}$-triphosphate (ATP), and Uridine $5^{\prime}$-triphosphate (UTP) from human umbilical vein endothelial cells (HUVECs) into the extracellular medium (in $500 \mu \mathrm{L}$ of supernatant) during hypoxia. Re-oxygenation has been studied at different times (T0, T15, T30, T60, T120, T135, T180, and T240 min) using liquid chromatography coupled with high resolution mass spectrometer (LC-HRMS). There was a significant and concomitant increase in ATP, ADP, AMP, and adenosine concentrations during hypoxia. Contrary to the nucleotides, adenosine concentrations remained steady during re-oxygenation (Figure 1, Supplementary file 1). Concentrations of ATP and adenosine were the most important during the experiment (Figure 1A,B). Extracellular concentration of ATP increased significantly for $15 \min (108.4 \pm 37.4 \mathrm{nM}, p<0.05)$ after the onset of hypoxia compared to the control group (T0: $2.0 \pm 1.0 \mathrm{nM}$ ). Concentration of ATP decreased rapidly after $30 \mathrm{~min}(55.2 \pm 17.7 \mathrm{nM}, p<0.05 \mathrm{vs}$. control group T0, and T60: $15.8 \pm 5.9 \mathrm{nM}, p<0.05)$ and was undetectable after $60 \mathrm{~min}$ of hypoxia. Extracellular concentration of adenosine increased significantly $(p<0.05)$ during hypoxia and re-oxygenation $(\mathrm{T} 15: 127.2 \pm 33.6 \mathrm{nM}, \mathrm{T} 30: 142.2 \pm 37.4 \mathrm{nM}$, T60: $134.7 \pm 26.1 \mathrm{nM}$ vs control group T0: $18.7 \pm 3.7 \mathrm{nM}$ ). After $60 \mathrm{~min}$, extracellular concentration of adenosine decreased but remained significantly $(p<0.05)$ higher than the concentration of the control group (T120: $71.1 \pm 7.5 \mathrm{nM}$ ). During the subsequent re-oxygenation period, adenosine concentration remained stable (T135: $82.3 \pm 3.7 \mathrm{nM}$, T180: $108.5 \pm 3.7 \mathrm{nM}, \mathrm{T} 240: 112.3 \pm 3.7 \mathrm{nM}$ ), while ATP was undetectable. 

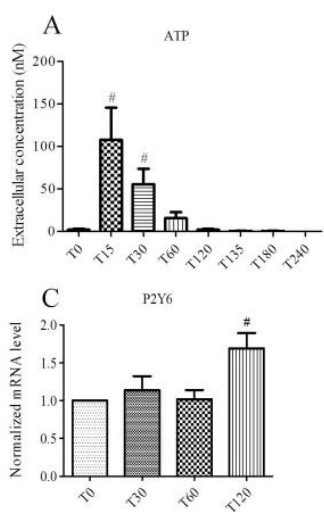

E
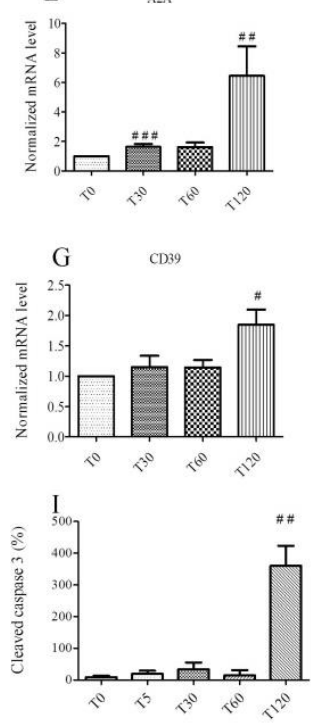
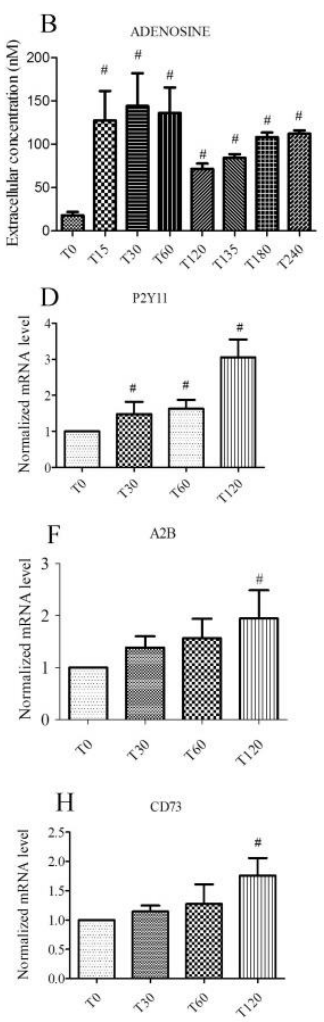

Figure 1. Effect of a 2-h hypoxia on endothelial cells. Extracellular ATP (A) and adenosine (B) concentrations are expressed in nM, during hypoxia (T0-T120) and at re-oxygenation (T135-T240). Overexpression of mRNA for P2Y6 (C) and P2Y11 (D) receptors, adenosine receptors A2A (E), A2B $(\mathbf{F})$, and ectonucleotidases CD39 (G) and CD73 (H) expressed with normalized mRNA levels using the following formula: $2^{-\Delta \Delta C T}$ as a function of time. Relative expression of cleaved caspase 3 by immunoblotting during hypoxia (I). Results are expressed as means $\pm \operatorname{sem}(n=6 /$ group). \#: $p<0.05$, \#\#: $p<0.01$, \#\#: $p<0.001$ compared to T0 group.

2.2. Hypoxic Stress Induces Overexpression of $P 2 Y_{6}, P 2 Y_{11}, A_{2 A}, A_{2 B}, C D 39$, and $C D 73$ mRNAs

In our model, the expression of $\mathrm{P} 2 \mathrm{Y}$ receptors, adenosine receptors, and ectonucleotidases mRNA was studied during two hours of hypoxia. P2 $\mathrm{Y}_{1}, \mathrm{P}_{2} \mathrm{Y}_{2}, \mathrm{P}_{2} \mathrm{Y}_{4}, \mathrm{P} 2 \mathrm{Y}_{6}, \mathrm{P} 2 \mathrm{Y}_{11}, \mathrm{P} 2 \mathrm{X}_{7}, \mathrm{P} 2 \mathrm{X}_{4}, \mathrm{~A}_{2 \mathrm{~A}}, \mathrm{~A}_{2 \mathrm{~B}}$, and $\mathrm{A}_{3}$ receptors were expressed in HUVECs (data not shown). The relative expression to the control group (T0) was estimated as normalized mRNA levels using the following formula: $2^{-\Delta \Delta C_{T}}$ of different conditions. Increased expression of mRNA was significant $(p<0.05)$ for P2Y $\mathrm{Y}_{6}$ (T120: $\left.1.69 \pm 0.20\right)$, $\mathrm{P}_{11}$ (T30: $1.48 \pm 0.34, \mathrm{~T} 60: 1.630 \pm 0.24$ and T120: $3.05 \pm 0.49$ ), $\mathrm{A}_{2 \mathrm{~A}}$ (T30: $1.63 \pm 0.19$ and T120: $6.44 \pm 1.99)$, and $\mathrm{A}_{2 \mathrm{~B}}$ (T120: $\left.1.943 \pm 0.54\right)$. Increased expression of mRNA was also significant $(p<0.05)$ for ectonucleotidases CD39 T120: $1.849 \pm 0.247$ and CD73 T120: $1.761 \pm 0.297$, involved in the conversion of ATP into adenosine (Figure 1C-H).

\subsection{Hypoxia Promotes Apoptosis in Endothelial Cells}

HUVECs were exposed to simulated hypoxia for two hours. Cells were harvested to analyze the expression of cleaved caspase 3 at different times. Stress related to hypoxia resulted in a significant increase in apoptosis of HUVECs. Relative expression to the control group (T0) of cleaved caspase 
3 was increased after 2 h of hypoxia: T120: $1029 \pm 181.3 \%$ vs control group T0 $100 \%, n=6, p<0.05$, Figure 1I). The lactate dehydrogenase activity (LDH) measured after $2 \mathrm{~h}$ of hypoxia experiment did not change significantly (Supplementary file 2). Hypoxia induced apoptosis without inducing LDH release.

\subsection{Extracellular ATP and Adenosine Induced an Anti-Apoptotic Effect}

An anti-apoptotic effect of extracellular ATP was assessed in HUVECs treated with ATP $(1 \mu \mathrm{M}$, $5 \mu \mathrm{M}, 10 \mu \mathrm{M}$ and $50 \mu \mathrm{M})$ for two hours of hypoxia. A significant decrease $(n=6, p<0.05)$ in the relative expression of cleaved caspase 3 was observed in cells treated with $5 \mu \mathrm{M} \mathrm{ATP}(59 \pm 7.9 \%)$, $10 \mu \mathrm{M}(38 \pm 8.2 \%)$ and $50 \mu \mathrm{M}(4 \pm 1.1 \%)$ versus control group 100\% (Figure $2 \mathrm{~A})$. The anti-apoptotic effect of extracellular adenosine was also assessed in HUVECs treated with adenosine $(1 \mu \mathrm{M}, 5 \mu \mathrm{M}$ and $10 \mu \mathrm{M})$ before $2 \mathrm{~h}$ of hypoxia. A significant decrease $(n=6, p<0.05)$ of relative expression of cleaved caspase 3 was observed in cells treated with $1 \mu \mathrm{M}$ adenosine $(55.33 \pm 9.82 \%), 5 \mu \mathrm{M}(37.67 \pm 4.91 \%)$, and $10 \mu \mathrm{M}(26 \pm 7 \%)$ vs. a control group of $100 \%$ (Figure $2 \mathrm{~B}$ ).

A

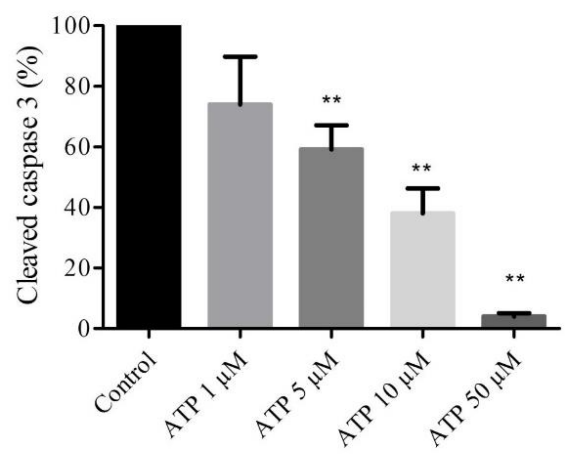

B

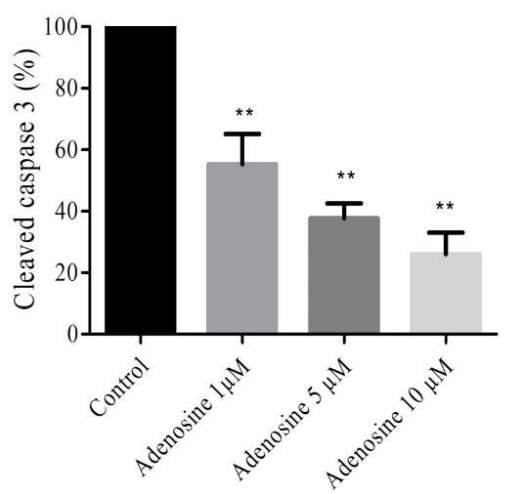

Figure 2. ATP and adenosine induced an anti-apoptotic effect. Cells were treated with ATP $1 \mu \mathrm{M}, 5 \mu \mathrm{M}$, $10 \mu \mathrm{M}$, and $50 \mu \mathrm{M}(\mathbf{A})$ and adenosine $1 \mu \mathrm{M}, 5 \mu \mathrm{M}$, and $10 \mu \mathrm{M}(\mathbf{B})$. Results are expressed as means \pm sem ( $n=6$ /group) of relative caspase 3 expression (\%) in the HUVECs after 2 h of hypoxia. ${ }^{* *} p<0.01$ compared to control without any treatment.

\subsection{Protective Effects of Extracellular ATP Are Mediated by P2 and Adenosine Receptors}

The role of P2 and P1 receptors involved in the anti-apoptotic effect of extracellular ATP was investigated using a panel of selective antagonists (Table 1). Treatment was performed with $10 \mu \mathrm{M}$ ATP and P2 antagonists, $10 \mu \mathrm{M}$ suramin or pyridoxalphosphate-6-azophenyl-2' $4^{\prime}$ '-disulfonic acid (PPADS) or adenosine antagonist (1 $\mu \mathrm{M}$ CGS15943) (Figure 3A). The anti-apoptotic effect of $10 \mu \mathrm{M}$ ATP was partially abolished by $10 \mu \mathrm{M}$ suramin $(76.75 \pm 20.70 \%)$, by $10 \mu \mathrm{M}$ PPADS (52.8 $\pm 20.6 \%$ ), or by CGS15943 (48.61 $\pm 6.87 \%)$ compared to cells treated with $10 \mu \mathrm{M}$ ATP alone $(7.5 \pm 2.1 \% ; n=9, p<0.05)$. 
These results suggest that $\mathrm{P} 2$ and adenosine receptors are involved in the anti-apoptotic effect triggered by ATP (Figure 3A). Compared to control, only suramin increased cleaved caspase $3(p<0.01)$.

Table 1. Panel of inhibitors and antagonists.

\begin{tabular}{cccc}
\hline Compounds Name & Target & Concentration & Reference \\
\hline Suramin & P2 receptors antagonist & $10 \mu \mathrm{M}$ & Wee et al. [12] \\
\hline PPADS & P2 receptors antagonist & $10 \mu \mathrm{M}$ & Wee et al. [12] \\
\hline CGS 15943 & Adenosine receptors antagonist & $1 \mu \mathrm{M}$ & Avanzato et al. [16] \\
\hline SCH442416 & selective receptor antagonist A2A & $10 \mu \mathrm{M}$ & Yu et al. [17] \\
\hline MRS1754 & selective receptor antagonist A2B & $0.1 \mu \mathrm{M}$ & Salie et al. [18] \\
\hline MRS1191 & selective receptor antagonist A3 & $10 \mu \mathrm{M}$ & Salie et al. [18] \\
\hline U0126 & ERK1/2 inhibitor & $10 \mu \mathrm{M}$ & Urban et al. [19] \\
\hline LY294002 & PI3K inhibitor & $10 \mu \mathrm{M}$ & Urban et al. [19] \\
\hline 5-HD & mitoK ATP inhibitor & $100 \mu \mathrm{M}$ & Millart et al. [20] \\
\hline L-NAME & NOS inhibitor & $10 \mu \mathrm{M}$ & Millart et al. [20] \\
\hline H89 & PKA inhibitor & $20 \mu \mathrm{M}$ & Millart et al. [20] \\
\hline indomethacin & COX inhibitor & $5 \mu \mathrm{M}$ & Alm et al. [21] \\
\hline
\end{tabular}

This table shows the different inhibitors and antagonists used for experiments. Concentrations and references are quoted.

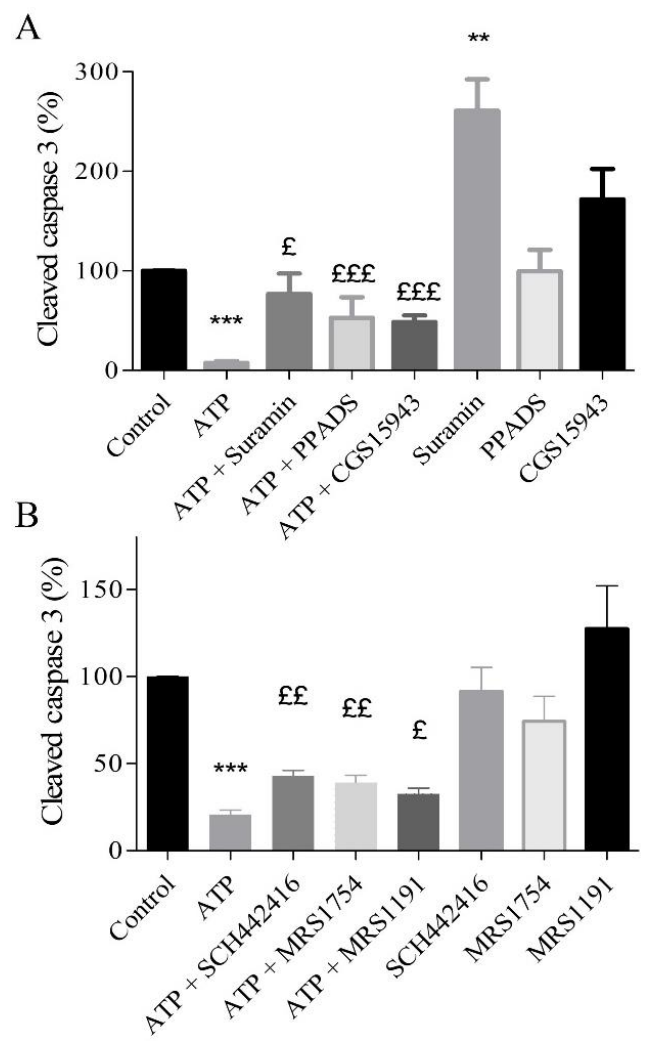

Figure 3. Anti-apoptotic effect of extracellular ATP mediated by both P2 and adenosine receptors (A). HUVECs, exposed to a simulated hypoxia during $2 \mathrm{~h}$, were treated with ATP $10 \mu \mathrm{M}, \mathrm{P} 2$ antagonist (10 $\mu \mathrm{M}$ suramin and PPADS), and adenosine antagonist (1 $\mu \mathrm{M}$ CGS15943). Subtypes of adenosine receptors were studied using selective receptors antagonists (B) of A2A (10 $\mu \mathrm{M} \mathrm{SCH442416),} \mathrm{A2B}$ (0.1 $\mu \mathrm{M}$ MRS1754), and A3 (10 $\mu \mathrm{M}$ MRS1191) receptors. Data are means $\pm \operatorname{sem}(n=6 /$ group $)$ of relative caspase 3 expression (\%) in HUVECs after 2 h of hypoxia. ${ }^{£} p<0.05,{ }^{£ £} p<0.01,{ }^{£ £} p<0.001$ compared to $10 \mu \mathrm{M}$ ATP group. ${ }^{* *} p<0.01,{ }^{* * *} p<0.001$ compared to control without treatment. 
2.6. P2 Receptor-Mediated Anti-Apoptotic Effect of ATP Involves PI3K, MEK/ERK1/2, mitoK $_{A T P}$, and NOS Pathways

To assess the signaling pathways involved in the P2 receptor-mediated effect, HUVECs were treated with $1 \mu \mathrm{M}$ CGS15943 and different inhibitors (Table 1): $10 \mu \mathrm{M}$ U0126 (MEK/ERK1/2), $10 \mu \mathrm{M}$ LY294002 (PI3K), $100 \mu \mathrm{M}$ 5-hydroxydecanoate (5-HD, mitoK ${ }_{\text {ATP }}$ channel), and $10 \mu \mathrm{M}$ $\mathrm{N}(\omega)$-nitro-L-arginine methyl ester (L-NAME, NOS), $20 \mu \mathrm{M}$ H89 (PKA), and $5 \mu \mathrm{M}$ indomethacin (Cyclooxygenase COX). The anti-apoptotic effect of $10 \mu \mathrm{M}$ ATP and $10 \mu \mathrm{M}$ ATP $+1 \mu \mathrm{M}$ CGS15943 was unaffected by blocking PKA and COX pathway (data not shown). Compared to the control, we observed no difference with U0126, H89, L-NAME, or 5-HD, while no significant increase was observed with LY294002 (Supplementary file 3).

The anti-apoptotic effect (relative to control) of $10 \mu \mathrm{M}$ ATP $(18 \pm 6.6 \%)$ during hypoxia was abolished by blocking MEK/ERK1/2 pathway $(89 \pm 32.5 \%, p<0.05)$. This result was also observed in cells co-treated with ATP and CGS15943 vs. ATP + CGS15943 + U0126. The anti-apoptotic effect of $10 \mu \mathrm{M}$ ATP and $1 \mu \mathrm{M}$ CGS15943 $(39.23 \pm 6.52 \%)$ was significantly and partially abolished by blocking MEK/ERK1/2 (91.57 $\pm 21.30 \%)$, PI3K $(112.8 \pm 27.42 \%)$, mitoK ${ }_{\mathrm{ATP}}(66.17 \pm 8.88 \%)$, and NOS $(75.80 \pm 5.7 \%)$ pathway $(n=6, p<0.05)$, with $10 \mu \mathrm{M}$ U0126 (MEK/ERK1/2), $10 \mu \mathrm{M}$ LY294002 (PI3K),

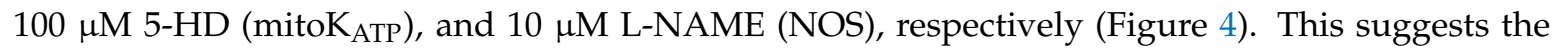
involvement of MEK/ERK1/2, PI3K, mitoK ${ }_{\mathrm{ATP}}$ channel, and NOS in P2 signaling.
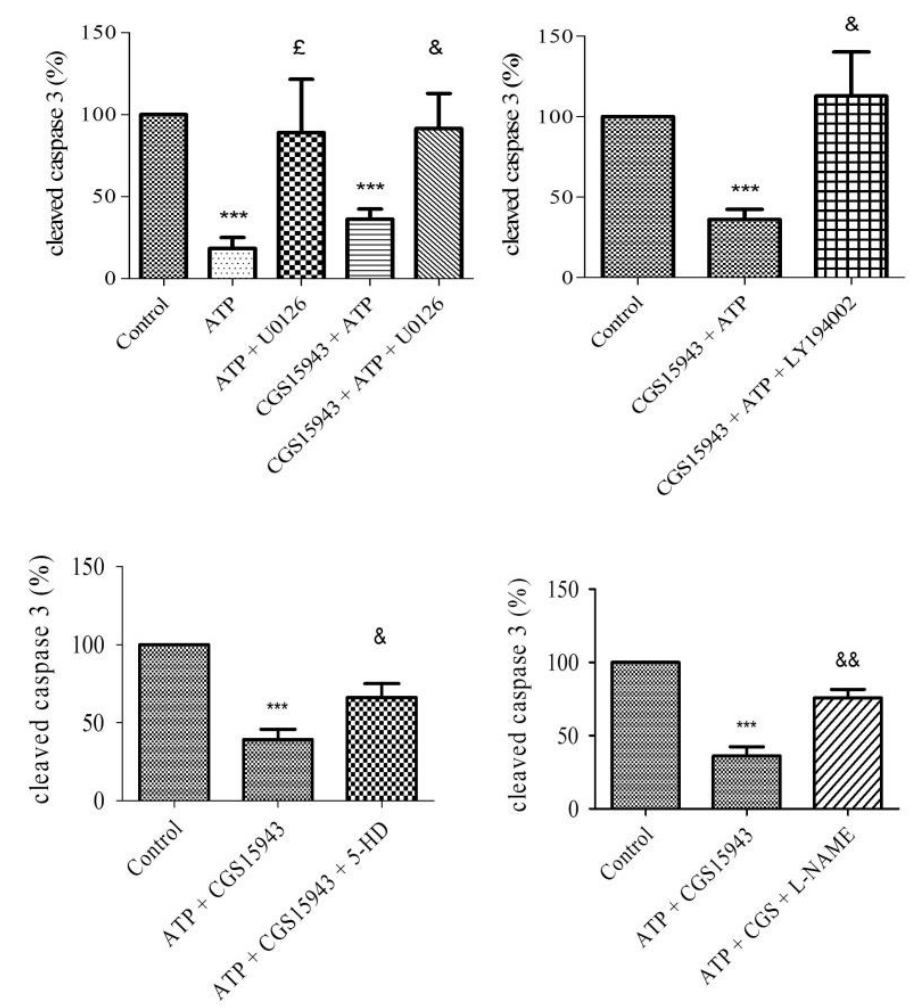

Figure 4. Signaling pathways involved in the P2-mediated anti-apoptotic effect of ATP. HUVECs were treated with different antagonists: $10 \mu \mathrm{M}$ U0126 (MEK/ERK1/2), $10 \mu \mathrm{M} \mathrm{LY294002} \mathrm{(PI3K),} 100 \mu \mathrm{M}$

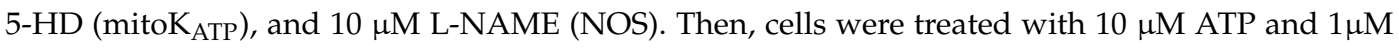
CGS15943 and submit to $2 \mathrm{~h}$ of hypoxia. Data are means $\pm \operatorname{sem}(n=6 /$ group $)$ of relative caspase 3 expression (\%) in HUVECs after 2 h of hypoxia. ${ }^{£} p<0.05$, compared to $10 \mu \mathrm{M}$ ATP group. ${ }^{\&} p<0.05$, $\& \& p<0.01$ compared to $10 \mu \mathrm{M}$ ATP $+1 \mu \mathrm{M}$ CGS15943 group. ${ }^{* * *} p<0.001$ compared to the control.

\section{7. $A_{2 A}, A_{2 B}$, and $A_{3}$ Receptors are Involved in Endothelial Protection Induced by Extracellular ATP}

To highlight the role adenosine receptors in the endothelial protection by extracellular ATP during hypoxia, pharmacological approach using selective antagonists was performed (Table 1). HUVECs 
were treated with $10 \mu \mathrm{M} \mathrm{SCH} 442416$ (a selective $\mathrm{A}_{2 \mathrm{~A}}$ receptor antagonist), $0.1 \mu \mathrm{M}$ MRS1754 (selective $\mathrm{A}_{2 B}$ receptor antagonist), or $10 \mu \mathrm{M}$ MRS1191 (selective $A_{3}$ receptor antagonist). Then, $10 \mu \mathrm{M}$ ATP were added prior to two hours of hypoxia. The expression of cleaved caspase 3 was compared to the control (10 $\mu \mathrm{M}$ ATP). The anti-apoptotic effect of $10 \mu \mathrm{M}$ ATP (cleaved caspase 3 related to control: $20.82 \pm 2.43 \%)$ was significantly limited in cells after blockade of the $\mathrm{A}_{2 \mathrm{~A}}$ receptor $(42.80 \pm 3.27 \%)$, the $\mathrm{A}_{2 \mathrm{~B}}$ receptor $(39.00 \pm 4.25 \%)$, and the $\mathrm{A}_{3}$ receptor $(32.60 \pm 3.32 \%)(n=6, p<0.05)$ (Figure $\left.3 \mathrm{~B}\right)$.

\subsection{Adenosine Receptor-Mediated Anti-Apoptotic Effect Involves MEK/ERK1/2, PKA, and NOS}

To highlight the mechanism of adenosine-mediated protection against caspase- 3 cleavage, HUVECs were treated with different antagonists (Table 1): $10 \mu \mathrm{M}$ U0126 (MEK/ERK1/2), $10 \mu \mathrm{M}$

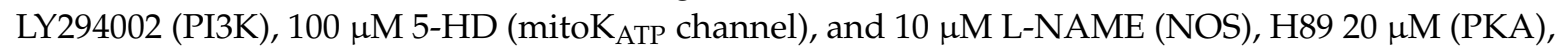
and $5 \mu \mathrm{M}$ indomethacin (COX) and then with $10 \mu \mathrm{M}$ adenosine prior to two hours of hypoxia. The anti-apoptotic effect of adenosine $10 \mu \mathrm{M}$ was unaffected by blocking COX, PI3K, and mitoK ATP $_{\text {, }}$ channel pathway (data not shown). The expression of cleaved caspase 3 was performed and compared to the control (adenosine $10 \mu \mathrm{M})$. The anti-apoptotic effect of $10 \mu \mathrm{M}$ adenosine $(19 \pm 1.82 \%)$ was significantly limited in cells by blocking MEK/ERK1/2 (49.75 $\pm 13.46 \%)$, PKA $(54.25 \pm 9.65 \%)$, and the $\operatorname{NOS}(57.75 \pm 14.01 \%)$ pathway $(n=6, p<0.05)$ (Figure 5$)$.
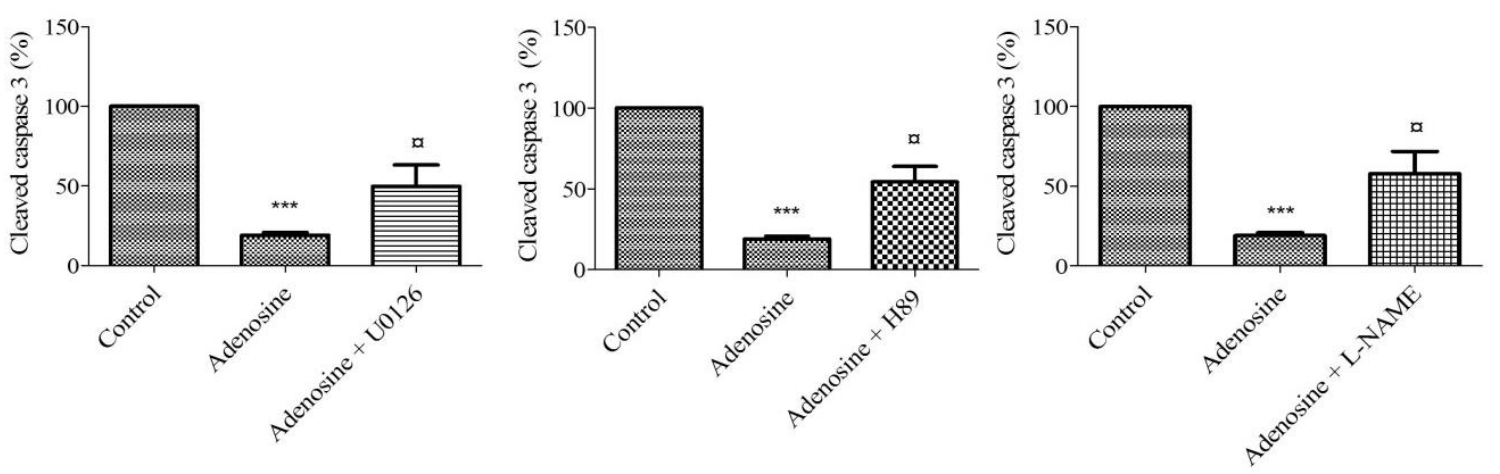

Figure 5. Signaling pathways involved in the anti-apoptotic effect of adenosine. HUVECs were treated with different antagonists: $10 \mu \mathrm{M}$ U0126 (MEK/ERK1/2), $20 \mu \mathrm{M}$ H89 (PKA), and $10 \mu \mathrm{M}$ L-NAME (NOS). Results are expressed as means \pm sem ( $n=6$ /group) of relative caspase 3 expression (\%) in HUVECs after $2 \mathrm{~h}$ of hypoxia. ${ }^{\alpha} p<0.05$, compared to $10 \mu \mathrm{M}$ adenosine group. ${ }^{* * *} p<0.001$ compared to the control.

\section{Discussion}

In this study, we evaluated the anti-apoptotic effect of extracellular ATP against hypoxic injury in a model of human umbilical vein endothelial cells. The main findings of this study are as follows: (1) Hypoxic stress was associated with a significant release of ATP from endothelial cells. (2) This was associated with an increase in the extracellular concentration of adenosine. (3) The anti-apoptotic effect of extracellular ATP was mediated by both P2 and adenosine receptors. The MEK/ERK1/2,

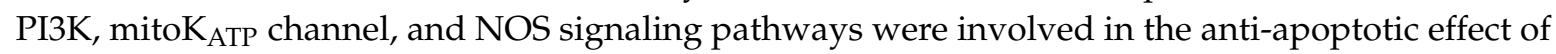
extracellular ATP. (4) $\mathrm{A}_{2 \mathrm{~A}}, \mathrm{~A}_{2 \mathrm{~B}}$, and $\mathrm{A}_{3}$ receptors were involved in the anti-apoptotic effect of ATP. Adenosine-mediated protection involved the MEK/ERK1/2, PKA, and NOS pathways. ATP and adenosine share common signaling pathways such as MEK/ERK $1 / 2$ and NOS.

In our model, endothelial cells were subjected to hypoxic stress $\left(\mathrm{pO}_{2}<2 \%\right)$ [22] for two hours [23]. Compared to normoxic conditions in human umbilical vein blood, hypoxia was considered in HUVEC when an $\mathrm{O}_{2}$ content was less than 2\% [22]. An important release of ATP rapidly occurred, within the first $15 \mathrm{~min}$ after the onset of hypoxia. The concentration of ATP then rapidly decreased after $30 \mathrm{~min}$ and was undetectable after $60 \mathrm{~min}$ of hypoxia. In response to a large variety of stimuli, ATP can be released from cells [19,24-26]. Gerasimovskaya et al. [24] reported that hypoxia induced the release of ATP into 
the extracellular medium from both adventitial fibroblasts and endothelial cells. They observed an ATP concentration, which peaked at $5 \mathrm{nM}$ after $30 \mathrm{~min}$ of hypoxic stress. Urban et al. [19] reported a 2.5-fold increase of extracellular ATP after $10 \mathrm{~min}$ of simulated hypoxia. As in our model, they reported a rapid decrease in extracellular ATP after $30 \mathrm{~min}$, which was undetectable after $60 \mathrm{~min}$ of hypoxia. Extracellular peak concentration of ATP reached around $108 \mathrm{nM}$ in our model. In plasma sampling, different studies reported concentrations of ATP ranging from 28 to 11,000 nM [27].

With a half-life of approximately $20 \mathrm{~s}$ [28], ATP generates ADP, AMP, and adenosine under the action of ectonucleotidases $[9,29]$. Our result also showed a seven-fold increase in extracellular adenosine in the first stages of hypoxia and a sustained increase at re-oxygenation. Initial studies indicated that the half-life of extracellular adenosine increased fivefold after exposure of the endothelial cells to hypoxic conditions [30]. Conde et al. [31] studied adenosine release during hypoxia from the rat carotid body. Using a nucleotidase inhibitor, they suggested in their model that approximately $40 \%$ of extracellular adenosine came from the extracellular catabolism of ATP [31]. Casanello et al. reported adenosine concentrations of $1800 \mathrm{nM}$ after $24 \mathrm{~h}$ of hypoxia of endothelial cells [22]. Harrison et al. and Djerada et al. also reported an increase in adenosine concentration (ranging 0.3-18 $\mu \mathrm{M}$ ) in interstitial fluid during ischemia/reperfusion in a Langendorff heart model [15,32]. In addition, during hypoxia, an increase in extracellular adenosine production has been reported as a result of increased enzymatic activity of both CD39 and CD73 [30]. Uptake of extracellular adenosine is impaired during hypoxia due to reduced expression of equilibrative nucleoside transporters (ENTs) [22,33-36]. Lastly, during acute hypoxia, a reduction of adenosine deaminase catabolism was reported [37]. Together, these studies can explain the sustained extracellular adenosine concentrations (Figure 1B, Supplementary file 1).

This current study confirmed the expression of ectonucleotidases, $\mathrm{P} 2$, and adenosine receptors in endothelial cells. According to the literature, $\mathrm{P}_{2} \mathrm{Y}_{1}, \mathrm{P}_{2} \mathrm{Y}_{2}, \mathrm{P}_{2} \mathrm{Y}_{4}, \mathrm{P}_{2} \mathrm{Y}_{6}, \mathrm{P}_{2} \mathrm{Y}_{11}, \mathrm{P} 2 \mathrm{X}_{7}, \mathrm{P} 2 \mathrm{X}_{4}, \mathrm{~A}_{2 \mathrm{~A}}$, $A_{2 B}$, and $A_{3}$ receptors are expressed in endothelial cells. Wang et al. reported that, among the $P 2$ receptors, the expression of $\mathrm{P}_{2} \mathrm{X}_{4}, \mathrm{P}_{2} \mathrm{Y}_{11}, \mathrm{P}_{2} \mathrm{Y}_{1}$, and $\mathrm{P} 2 \mathrm{Y}_{2}$ was preponderant in endothelial cells [38] whereas, regarding adenosine receptors, $A_{2 A}$ and $A_{2 B}$ receptors are mostly expressed $[9,39]$. We also demonstrated the expression of ectonucleotidases CD39 and CD73 in endothelial cells, according to the literature [40].

To demonstrate that ATP and adenosine exert a complementary role in protection against hypoxic stress, we used a non-selective adenosine antagonist (CGS15943) and two P2 receptor antagonists (suramin and PPADS). The ATP concentration used was $10 \mu \mathrm{M}$ since, at this concentration, expression of cleaved caspase 3 was significantly reduced (Figure 4). First, suramin or PPADS, two P2 antagonists, reduced the protective effect of ATP against hypoxic stress. In agreement with the literature, our results suggest the involvement of P2 in protection against hypoxia $[8,12,13,19,20]$. The fact that CGS15943 counteracted the anti-apoptotic effect of ATP in response to hypoxia further suggests that both adenosine and P2 receptors play a complementary role in the protective effect against hypoxia [13].

Compared to the control, CGS15943 did not significantly increase cleaved caspase 3, while a significant effect was observed with suramin. These results can be explained by the suppression of the protective effect of the endogenous nucleotides released during hypoxia.

The involvement of multiple signaling pathways has been described in the P2Y-mediated cardioprotection against ischemia [8]. The set-up of our protocol using $1 \mu \mathrm{M}$ CGS15943 and then $10 \mu \mathrm{M}$ ATP $5 \mathrm{~min}$ before hypoxia was aimed at focusing on the protective P2-mediated effect of ATP. In agreement with the literature, the inhibition of MEK/ERK1/2 (U0126), PI3K (LY94002), mitoK $_{\text {ATP }}$ channel (5-HD), and NOS (L-NAME) reduced the anti-apoptotic effect of ATP. This emphasizes the major role of these signaling pathways in the protection against hypoxic or ischemic damage [19,41-44].

Our results also confirm the involvement of the Reperfusion Injury Salvage Kinase (RISK) pathway (both MEK/ERK1/2 and PI3K pathways) in P2-mediated protection. These data are consistent with the well-established role of the RISK pathway in the cardioprotective effects of ischemic preconditioning and post-conditioning $[8,40,42,45,46]$. 
The inhibition of the mitoK $\mathrm{K}_{\text {ATP }}$ channel by 5 -HD reduced the P2-mediated protection of ATP. We suggest that the mitoK $\mathrm{ATP}_{\mathrm{AT}}$ channel was involved in the protective effect of the ATP, as previously reported [20].

Using L-NAME, which is a NOS inhibitor, we observed a decrease in the protective effect of extracellular ATP. As suggested by Park et al., ATP can activate the P2Y receptors on the endothelium and the downstream Nitric oxid/guanosine monophosphate pathway [44].

On the one hand, among the receptors expressed in our model, only P2Y receptors could be blocked by $10 \mu \mathrm{M}$ of suramin [47]. The suppression of the ATP-induced protective effect by PPADS, known as a P2Y and P2X receptor antagonist (P2X1,2,3,4,4, and 7 with higher concentrations, i.e., $100 \mu \mathrm{M}$ ) [48], may suggest that P2X receptors are involved especially those expressed in our model such as P2X4 and P2X7 receptors. On the other hand, it has been reported that alpha-methyl ATP, used at concentrations between 0.1 and $300 \mu \mathrm{M}$, activates all P2X receptors [49]. Using ascending concentrations of alpha-methyl ATP $(10,100,1000 \mu \mathrm{M})$, Urban did not observe any anti-apoptotic effects in HUVEC cells. In addition, the fact that the anti-apoptotic effect of ATP involved the PI3K, MEK/ERK1/2, mitoKATP, and NOS pathways suggests an engagement of $G$ protein-coupled receptors such as P2Y receptors [19]. Lastly, the P2Y receptors seem to be more likely involved than P2X receptors in the anti-apoptotic effect induced by extracellular ATP.

Selective antagonist of $A_{2 A}, A_{2 B}$, and $A_{3}$ receptors limited the anti-apoptotic of ATP against hypoxia. $A_{2 A}$ receptor has been identified as having cardioprotective and renal protective effect [50-52]. $A_{2 B}$ receptor has been documented to contribute to cardioprotection $[18,50,53]$. Other authors also reported $\mathrm{A}_{3}$ adenosine receptor-mediated protection of the ischemic heart $[18,50,54,55]$.

Adenosine uptake inhibition by ticagrelor and cangrelor is associated with a protective effect in an in-vivo model of heart ischemia [56]. Moreover, it has been reported that cardioprotection by cangrelor involved PI3K/Akt and MEK/ERK1/2 pathways [57]. They also reported an involvement of mitoK $\mathrm{K}_{\mathrm{ATP}}$ channel and $\mathrm{A}_{2 \mathrm{~B}}$ receptor.

We observed a limited protective effect of adenosine with L-NAME, which is a NOS inhibitor. Our results suggest that the activation of adenosine receptors involved NO production, which is in agreement with Nanhwan et al. [56]. The release of mediators such as nitric oxide might represent a paracrine communication between cardiac endothelial cells and cardiomyocytes, which provides remote protection for cardiac cells. In addition, $\mathrm{NO}$ has been found to mediate cardioprotective effects $[7,46]$.

Our results did not highlight the involvement of the COX pathway. This is in contrast with a previous study reporting a cardioprotective effect of ticagrelor dependent on adenosine and the cox pathway [56].

Our results demonstrated an involvement of the MEK/ERK1/2, NOS, and PKA pathways in adenosine-mediated protection. It has been reported that adenosine-mediated cardioprotective effects involve different signaling pathways, such as MEK/ERK1/2, PI3K/Akt, NOS, PKA, and COX [50,58]. These discrepancies can be explained by differences between in-vivo and/or in-vitro models of isolated heart and in-vitro cultured HUVECs and differences in the receptor expression.

\section{Materials and Methods}

\subsection{Cell Culture}

HUVECs were purchased from PromoCell (Sickingenstraße, Heidelberg, Germany) and cultured in endothelial cell growth medium (PromoCell) containing 2\% $(v / v)$ Fetal Coat Serum (FCS), 0.4\% $(v / v)$ endothelial growth supplement: $0.1 \mathrm{ng} / \mathrm{mL}$ human Epidermal Growth Factor (EGF), $1.0 \mu \mathrm{g} / \mathrm{mL}$ hydrocortisone, $1 \mathrm{ng} / \mathrm{mL}$ human basic fibroblast growth factor (bFGF), $90 \mu \mathrm{g} / \mathrm{mL}$ heparin, and $1 \%$ $(v / v)$ penicillin/streptomycin (DUTSCHER SAS, Brumath, France) in a fully humidified atmosphere at $37^{\circ} \mathrm{C}$ and $5 \% \mathrm{CO}_{2}$. Confluent cells were detached with the PromoCell detach kit (Sickingenstraße, Heidelberg, Germany) containing $30 \mathrm{mM}$ Hepes, Trypsin/EDTA Solution (0.04\%/0.03\%), and Trypsin 
Neutralizing Solution. FCS was reduced to $1 \% 24 \mathrm{~h}$ before the experiment. All experiments were performed on subconfluent endothelial monolayer cells (80\%) after the third passage.

\subsection{Experimental Protocols}

Cells were placed into a custom-made hypoxic chamber (Bactron, Sheldon Manufacturing Inc, Cornelius, NC, USA) and exposed to $95 \%(v / v) \mathrm{N}_{2}$ and $5 \%(v / v) \mathrm{CO}_{2}$ for $2 \mathrm{~h}$ at $37^{\circ} \mathrm{C} \mathrm{PO}_{2}$ in the hypoxic chamber was reduced to less than $1.5 \%$ during the experiments. Control cells were cultured in parallel under normoxic conditions. During the experiments, cells and medium were harvested at different times for cytotoxic analysis (Lactate dehydrogenase LDH activity), Real-time polymerase chain reaction (RT-PCR) analysis, and quantification of nucleotides in the medium. After $2 \mathrm{~h}$ of hypoxia, the cleavage of caspase 3 was evaluated by immunoblotting.

Adenosine, AMP, ADP, and ATP were purchased from Sigma-Aldrich (St. Louis, MO, USA). Ligands were added just before hypoxia. P2-receptor antagonists suramin (Sigma-Aldrich, Saint-Louis, MO, USA) and PPADS (Tocris, Bristol, United Kingdom), Adenosine receptor antagonists CGS15943 (Sigma-Aldrich, Saint-Louis, MO, USA), SCH442416 (Sigma-Aldrich, Saint-Louis, MO, USA), MRS1754 (Sigma-Aldrich, Saint-Louis, MO, USA), and MRS1191 (Sigma-Aldrich, Saint-Louis, MO, USA) were added $15 \mathrm{~min}$ before hypoxia. The MEK/ERK1/2-inhibitor U0126 (Sigma-Aldrich, Saint-Louis, MO, USA), the PI3K-inhibitor LY294002 (Sigma-Aldrich, Saint-Louis, MO, USA), the PKA-inhibitor H-89 (Sigma-Aldrich, Saint-Louis, MO, USA), the mitoK ${ }_{\text {ATP }}$ channel inhibitor (5-HD, Sigma-Aldrich, Saint-Louis, MO, USA), the COX-inhibitor indomethacin (Sigma-Aldrich, Saint-Louis, MO, USA), the nitric oxide synthase (NOS), and the inhibitor L-(NAME Sigma-Aldrich, Saint-Louis, MO, USA) were added $15 \mathrm{~min}$ before hypoxia. All these compounds were dissolved in phosphate buffered saline (PBS) or dimethylsulfoxyde (DMSO, Bio Basic Inc, Markham, ON, Canada), according to their solubility. Final DMSO concentration was less than $0.1 \%$ in cell culture medium. Working concentrations of inhibitors and antagonists were the same as previously described (Table 1) $[12,16,17,19,20]$.

\subsection{Quantification of Nucleotides in Extracellular Medium}

Culture medium $(50 \mu \mathrm{L})$ was collected at different times during the course of each experiment. As described, to inhibit ectonucleotidase activity, $75 \mu \mathrm{L}(60 \% \mathrm{~V} / \mathrm{V})$ of methanol were added and the extracts were frozen at $-80^{\circ}$ [59-61]. Internal standard solution (nicotinamide D4 $10 \mu \mathrm{g} \mathrm{L}^{-1}$ ) was added. Mixtures were evaporated under nitrogen at $40{ }^{\circ} \mathrm{C}$ and then reconstituted with 100 $\mu \mathrm{L}$ of ice-cold water (Liquid Chromatography Mass Spectrometry (LC-MS) hypergrade). Liquid chromatography (Hypercarb column $5 \mu \mathrm{M}, 2.1 \times 150 \mathrm{~mm}$, ThermoFisher Scientific, San José, CA, USA) coupled with high-resolution mass spectrometer (LC-HRMS) was used for the quantification (ThermoFisher Scientific, San José, CA, USA). High-resolution mass for ATP $\left(\mathrm{C}_{10} \mathrm{H}_{16} \mathrm{~N}_{5} \mathrm{O}_{13} \mathrm{P}_{3}\right.$, negative mode ionization, $m / z 505.98847)$, for adenosine $\left(\mathrm{C}_{10} \mathrm{H}_{13} \mathrm{~N}_{5} \mathrm{O}_{4}\right.$, positive mode ionization, $m / z$ 268.10403), and for nicotinamide $\mathrm{D} 4\left(\mathrm{C}_{6} \mathrm{H}_{2} \mathrm{D}_{4} \mathrm{~N}_{2} \mathrm{O}\right.$, positive mode ionisation, $\mathrm{m} / \mathrm{z}$ 127.0804) were used for quantification. TraceFinder Forensic 3.3 was used for LC-MS, library management, acquisition, and processing. These assays were performed as previously described $[15,62,63]$.

\subsection{RT-PCR}

During the course of each experiment, cells were collected at T0 (control), T30, T60, T120, and T240 min. Total RNA was extracted using RNeasy Mini-KitTM (Qiagen, Courtaboeuf, France). cDNA synthesis was obtained from $1 \mu \mathrm{g}$ RNA using the iScript cDNA synthesis kit (Biorad, Marnes-la-Coquette, France). Real time PCR was performed with Sybr Green PCR reagents and analyzed on an ABI Prism 7500 Fast Real- Time PCR System (Applied Biosystems, ThermoFisher Scientific, San José, CA, USA). PCR was carried out in duplicate for each sample. EEF2 was used as the Housekeeping gene. Results are presented as normalized mRNA levels using the following formula: $2^{-\Delta \Delta C}$ T according to Livak et al. [64]. mRNA expression of ectonucleotidases, 
adenosine, and P2 receptors was assayed: forward and reverse oligonucleotide primers are described in Supplementary file 4.

\subsection{Immunoblotting}

Samples for Western Blot were collected as follows. After treatment, the cell culture medium was collected and cells were washed in fresh PBS 1X. Protein extraction was performed by adding $100 \mu \mathrm{L}$ of RIPA Buffer (Sigma-Aldrich) supplemented with protease and phosphatase inhibitor cocktails. Samples were sonicated three times for $10 \mathrm{~s}$ and then centrifuged $30 \mathrm{~min}$ at $16,000 \mathrm{~g}$ at $4{ }^{\circ} \mathrm{C}$. The Bradford assay was performed to quantify proteins in samples. Equal lysed cellular protein $(30 \mu \mathrm{g})$ were boiled in the sample loading buffer for 5 min before loading on $12.5 \%$ sodium dodecyl sulfate-polyacrylamide gel electrophoresis (SDS-PAGE) for electrophoretic separation and subsequently transferred into polyvinylidene difluoride membranes (Immun-Blot PVDF Membrane Bio-Rad, Hercules, CA, USA). After blocking with skimmed milk 5\% $(m / v)$ in TBS-T (Tris-Buffered Saline and TWEEN $200.05 \%(v / v)$ ) membranes were incubated with the primary antibody overnight at $4{ }^{\circ} \mathrm{C}$. After washing with TBS-T, membranes were incubated with appropriate horseradish peroxidase-labelled secondary antibodies (1 h, $30 \mathrm{~min}$ at room temperature) (Supplementary file 5). Immunoreactivity was detected with the Chemiluminescent HRP detection reagent (Millipore, Burlington, VT, USA). Quantification was performed by densitometric analysis using the Quantity One software of ChemiDoc XRS and ImageLab for reprocessing image and quantification (BioRad, Marnes-la-Coquette, France) [15].

\subsection{LDH Activity}

The activity of LDH was analyzed using the Pierce LDH Cytotoxicity Assay Kit, according to the manufacturer's instructions (ThermoFisher, Waltham, MA, USA). Medium was transferred into a new plate and mixed with the Reaction Mixture. After incubation at room temperature for $30 \mathrm{~min}$, the reaction was stopped by adding the Stop Solution. To determine LDH activity, the absorbance were measured at $490 \mathrm{~nm}$ and $680 \mathrm{~nm}$ by the plate-reading spectrophotometer Victor X3 (Perkin Elmer, Waltham, MA, USA).

\subsection{Statistical Analysis}

Statistical analyses were performed using the Prism 4.00 GraphPad Software, San Diego, CA, USA and R 3.1.4 (The R Foundation for Statistical Computing, http:/ / www.r-project.org). All data are expressed as mean \pm sem. Before applying the parametric unpaired $t$ test, the Gaussian distribution of data was assessed by the Shapiro-Wilk normality test and the Kolmogorov-Smirnov test. For non-parametric distribution, a Mann-Whitney test was used. For all significant differences concerning primary endpoints, a posteriori powers higher than $80 \%$ were checked. Boneferroni correction was applied in the case of multiple comparisons.

All $p$ values were two-tailed with statistical significance indicated by a value of $p<0.05[65,66]$.

\section{Conclusions}

The present study shows the complementary role of adenosine and P2 receptors in the endothelial protection induced by extracellular ATP against hypoxic stress. ATP can act directly after its binding to the $\mathrm{P} 2$ receptors, which leads to the activation of MEK/ERK1/2, PI3K/Akt, NOS, and the mitoK $\mathrm{ATP}_{\mathrm{AT}}$ channel. Adenosine, which is a metabolite of ATP, by binding to $\mathrm{A}_{2 \mathrm{~A}}, \mathrm{~A}_{2 \mathrm{~B}}$, and $\mathrm{A}_{3}$ receptors, leads to the activation of MEK/ERK1/2, PKA, and NOS. We have identified a complementary role of ATP and adenosine in the anti-apoptotic effect against endothelial cell hypoxia. P2 and adenosine receptors may be novel therapeutic targets to prevent the development of ischemic injury in various organs including the heart, brain, and kidney. 
Supplementary Materials: Supplementary materials can be found at http:/ / www.mdpi.com/1422-0067/20/ 6/1446/s1. Supplementary file 1: Extracellular kinetics of nucleotides and adenosine during hypoxia and re-oxygenation. Data are expressed relative to baseline as $\log _{10}$ (means \pm sem) $(n=6$ /group). Supplementary file 2: LDH activity of endothelial cells after $2 \mathrm{~h}$ of hypoxia. Data are means $\pm \operatorname{sem}\left(n=6 /\right.$ group). ${ }^{*} p<0.05$, compared to the negative control group. Supplementary file 3: Inhibitors of signaling pathways. HUVECs were treated with different antagonists: $10 \mu \mathrm{M}$ U0126 (MEK/ERK1/2), $10 \mu \mathrm{M}$ LY294002 (PI3K), $20 \mu \mathrm{M}$ H89 (PKA), $10 \mu \mathrm{M}$ L-NAME (NOS), and $100 \mu \mathrm{M}$ 5-HD (mitoKATP). Results are expressed as means $\pm \operatorname{sem}(n=$ 6 /group) of relative caspase 3 expression (\%) in HUVECs after 2 h of hypoxia. Supplementary file 4: Forward and reverse oligonucleotide primers for RT-PCR analysis. Supplementary file 5: Primary and secondary antibodies for immunoblotting analysis.

Author Contributions: Conceptualization, C.F., H.P., G.P., P.N., H.M. and Z.D.; Data curation, C.F., H.P., G.P., Y.C., F.O., and Z.D. Formal analysis, C.F., H.P., Y.C., F.O., H.M., and Z.D. Funding acquisition, P.N., H.M., and Z.D. Investigation, C.F., H.P., G.P., and Z.D. Methodology, C.F., H.M., and Z.D. Project administration, Z.D. Resources, C.F., H.P., G.P., F.O., P.N., and Z.D. Software, C.F., H.P., Y.C., F.O., H.M., and Z.D. Supervision, H.M. and Z.D. Validation, H.P., Y.C., P.N., H.M., and Z.D. Visualization, H.P. and Z.D. Writing-original draft, C.F. Writing-review \& editing, H.M. and Z.D.

Funding: This study was supported by the University of Reims Champagne-Ardenne.

Acknowledgments: We thank the laboratory staff of pharmacology for nucleotides/nucleosides quantification. The authors thank M. Colbourne of ProofreadMyEssay (United Kingdom) for his revision of a part of the English text.

Conflicts of Interest: C.F., H.P., G.P., F.O., Y.C., P.N., H.M., and Z.D. declare no financial relationships with any organizations that might have an interest in the submitted work. No other relationships or activities that could appear to have influenced the submitted work.

\section{References}

1. Mason, J.C. Cytoprotective pathways in the vascular endothelium. Do they represent a viable therapeutic target? Vascul. Pharmacol. 2016, 86, 41-52. [CrossRef] [PubMed]

2. Li, H.; Horke, S.; Förstermann, U. Vascular oxidative stress, nitric oxide and atherosclerosis. Atherosclerosis 2014, 237, 208-219. [CrossRef]

3. Fisher, M. Injuries to the vascular endothelium: Vascular wall and endothelial dysfunction. Rev. Neurol. Dis. 2008, 5 (Suppl. 1), S4-S11.

4. Singhal, A.K.; Symons, J.D.; Boudina, S.; Jaishy, B.; Shiu, Y.-T. Role of Endothelial Cells in Myocardial Ischemia-Reperfusion Injury. Vasc. Dis. Prev. 2010, 7, 1. [CrossRef] [PubMed]

5. Scarabelli, T.; Stephanou, A.; Rayment, N.; Pasini, E.; Comini, L.; Curello, S.; Ferrari, R.; Knight, R.; Latchman, D. Apoptosis of endothelial cells precedes myocyte cell apoptosis in ischemia/reperfusion injury. Circulation 2001, 104, 253-256. [CrossRef] [PubMed]

6. Parolari, A.; Rubini, P.; Cannata, A.; Bonati, L.; Alamanni, F.; Tremoli, E.; Biglioli, P. Endothelial damage during myocardial preservation and storage. Ann. Thorac. Surg. 2002, 73, 682-690. [CrossRef]

7. Yang, Q.; He, G.-W.; Underwood, M.J.; Yu, C.-M. Cellular and molecular mechanisms of endothelial ischemia/reperfusion injury: Perspectives and implications for postischemic myocardial protection. Am. J. Transl. Res. 2016, 8, 765-777.

8. Djerada, Z.; Feliu, C.; Richard, V.; Millart, H. Current knowledge on the role of P2Y receptors in cardioprotection against ischemia-reperfusion. Pharmacol. Res. 2016, 118, 5-18. [CrossRef]

9. Burnstock, G. Purinergic Signaling in the Cardiovascular System. Circ. Res. 2017, 120, 207-228. [CrossRef]

10. Erlinge, D.; Burnstock, G. P2 receptors in cardiovascular regulation and disease. Purinergic Signal. 2008, 4, 1-20. [CrossRef]

11. Djerada, Z.; Millart, H. Intracellular NAADP increase induced by extracellular NAADP via the P2Y11-like receptor. Biochem. Biophys. Res. Commun. 2013, 436, 199-203. [CrossRef]

12. Wee, S.; Peart, J.N.; Headrick, J.P. P2 purinoceptor-mediated cardioprotection in ischemic-reperfused mouse heart. J. Pharmacol. Exp. Ther. 2007, 323, 861-867. [CrossRef] [PubMed]

13. Ninomiya, H.; Otani, H.; Lu, K.; Uchiyama, T.; Kido, M.; Imamura, H. Complementary role of extracellular ATP and adenosine in ischemic preconditioning in the rat heart. Am. J. Physiol. Heart Circ. Physiol. 2002, 282, H1810-H1820. [CrossRef] [PubMed]

14. Cohen, M.V.; Downey, J.M. Adenosine: Trigger and mediator of cardioprotection. Basic Res. Cardiol. 2008, 103, 203-215. [CrossRef] 
15. Djerada, Z.; Peyret, H.; Dukic, S.; Millart, H. Extracellular NAADP affords cardioprotection against ischemia and reperfusion injury and involves the P2Y11-like receptor. Biochem. Biophys. Res. Commun. 2013, 434, 428-433. [CrossRef] [PubMed]

16. Avanzato, D.; Genova, T.; Fiorio Pla, A.; Bernardini, M.; Bianco, S.; Bussolati, B.; Mancardi, D.; Giraudo, E.; Maione, F.; Cassoni, P.; et al. Activation of P2X7 and P2Y11 purinergic receptors inhibits migration and normalizes tumor-derived endothelial cells via cAMP signaling. Sci. Rep. 2016, 6, 32602. [CrossRef]

17. YU, J.; HUANG, X.; WU, Q.; WANG, J.; YU, X.; ZHAO, P. Effect of A2A receptor antagonist (SCH 442416) on the mRNA expression of glutamate aspartate transporter and glutamine synthetase in rat retinal Müller cells under hypoxic conditions in vitro. Exp. Ther. Med. 2012, 3, 803-806. [CrossRef]

18. Salie, R.; Moolman, J.A.; Lochner, A. The mechanism of beta-adrenergic preconditioning: Roles for adenosine and ROS during triggering and mediation. Basic Res. Cardiol. 2012, 107, 281. [CrossRef]

19. Urban, D.; Härtel, F.V.; Gadiraju, K.; Gündüz, D.; Aslam, M.; Piper, H.M.; Noll, T. Extracellular ATP attenuates ischemia-induced caspase-3 cleavage in human endothelial cells. Biochem. Biophys. Res. Commun. 2012, 425, 230-236. [CrossRef]

20. Millart, H.; Alouane, L.; Oszust, F.; Chevallier, S.; Robinet, A. Involvement of P2Y receptors in pyridoxal-5'-phosphate-induced cardiac preconditioning. Fundam. Clin. Pharmacol. 2009, 23, $279-292$. [CrossRef]

21. Alm, R.; Edvinsson, L.; Malmsjö, M. Organ culture: A new model for vascular endothelium dysfunction. BMC Cardiovasc. Disord. 2002, 2, 8. [CrossRef]

22. Casanello, P.; Torres, A.; Sanhueza, F.; González, M.; Farías, M.; Gallardo, V.; Pastor-Anglada, M.; San Martín, R.; Sobrevia, L. Equilibrative nucleoside transporter 1 expression is downregulated by hypoxia in human umbilical vein endothelium. Circ. Res. 2005, 97, 16-24. [CrossRef]

23. Kumar, S.; Reusch, H.P.; Ladilov, Y. Acidic pre-conditioning suppresses apoptosis and increases expression of Bcl-xL in coronary endothelial cells under simulated ischaemia. J. Cell. Mol. Med. 2008, 12, 1584-1592. [CrossRef]

24. Gerasimovskaya, E.V.; Ahmad, S.; White, C.W.; Jones, P.L.; Carpenter, T.C.; Stenmark, K.R. Extracellular ATP is an autocrine/paracrine regulator of hypoxia-induced adventitial fibroblast growth. Signaling through extracellular signal-regulated kinase-1/2 and the Egr-1 transcription factor. J. Biol. Chem. 2002, 277, 44638-44650. [CrossRef]

25. Bodin, P.; Burnstock, G. Synergistic effect of acute hypoxia on flow-induced release of ATP from cultured endothelial cells. Experientia 1995, 51, 256-259. [CrossRef]

26. Bodin, P.; Burnstock, G. Purinergic signalling: ATP release. Neurochem. Res. 2001, 26, 959-969. [CrossRef]

27. Gorman, M.W.; Feigl, E.O.; Buffington, C.W. Human Plasma ATP Concentration. Clin. Chem. 2007, 53, 318-325. [CrossRef]

28. Picher, M.; Burch, L.H.; Boucher, R.C. Metabolism of P2 receptor agonists in human airways: Implications for mucociliary clearance and cystic fibrosis. J. Biol. Chem. 2004, 279, 20234-20241. [CrossRef]

29. Yegutkin, G.G. Nucleotide- and nucleoside-converting ectoenzymes: Important modulators of purinergic signalling cascade. Biochim. Biophys. Acta 2008, 1783, 673-694. [CrossRef]

30. Koeppen, M.; Eckle, T.; Eltzschig, H.K. Chapter 6-Interplay of Hypoxia and A2B Adenosine Receptors in Tissue Protection. In Advances in Pharmacology; Pharmacology of Purine and Pyrimidine Receptors; Jacobson, K.A., Linden, J., Eds.; Academic Press: New York, NY, USA, 2011; Volume 61, pp. 145-186.

31. Conde, S.V.; Monteiro, E.C. Hypoxia induces adenosine release from the rat carotid body. J. Neurochem. 2004, 89, 1148-1156. [CrossRef]

32. Harrison, G.J.; Willis, R.J.; Headrick, J.P. Extracellular adenosine levels and cellular energy metabolism in ischemically preconditioned rat heart. Cardiovasc. Res. 1998, 40, 74-87. [CrossRef]

33. Chaudary, N.; Naydenova, Z.; Shuralyova, I.; Coe, I.R. Hypoxia regulates the adenosine transporter, mENT1, in the murine cardiomyocyte cell line, HL-1. Cardiovasc. Res. 2004, 61, 780-788. [CrossRef]

34. Löffler, M.; Morote-Garcia, J.C.; Eltzschig, S.A.; Coe, I.R.; Eltzschig, H.K. Physiological roles of vascular nucleoside transporters. Arterioscler. Thromb. Vasc. Biol. 2007, 27, 1004-1013. [CrossRef]

35. Morote-Garcia, J.C.; Rosenberger, P.; Nivillac, N.M.I.; Coe, I.R.; Eltzschig, H.K. Hypoxia-inducible factor-dependent repression of equilibrative nucleoside transporter 2 attenuates mucosal inflammation during intestinal hypoxia. Gastroenterology 2009, 136, 607-618. [CrossRef] 
36. Rose, J.B.; Naydenova, Z.; Bang, A.; Eguchi, M.; Sweeney, G.; Choi, D.-S.; Hammond, J.R.; Coe, I.R. Equilibrative nucleoside transporter 1 plays an essential role in cardioprotection. Am. J. Physiol. Heart Circ. Physiol. 2010, 298, H771-H777. [CrossRef]

37. Eltzschig, H.K.; Faigle, M.; Knapp, S.; Karhausen, J.; Ibla, J.; Rosenberger, P.; Odegard, K.C.; Laussen, P.C.; Thompson, L.F.; Colgan, S.P. Endothelial catabolism of extracellular adenosine during hypoxia: The role of surface adenosine deaminase and CD26. Blood 2006, 108, 1602-1610. [CrossRef]

38. Wang, L.; Karlsson, L.; Moses, S.; Hultgårdh-Nilsson, A.; Andersson, M.; Borna, C.; Gudbjartsson, T.; Jern, S.; Erlinge, D. P2 receptor expression profiles in human vascular smooth muscle and endothelial cells. J. Cardiovasc. Pharmacol. 2002, 40, 841-853. [CrossRef]

39. Burnstock, G.; Ralevic, V. Purinergic signaling and blood vessels in health and disease. Pharmacol. Rev. 2014, 66, 102-192. [CrossRef]

40. Burnstock, G. Purine and pyrimidine receptors. Cell. Mol. Life Sci. 2007, 64, 1471-1483. [CrossRef]

41. Beitner-Johnson, D.; Rust, R.T.; Hsieh, T.C.; Millhorn, D.E. Hypoxia activates Akt and induces phosphorylation of GSK-3 in PC12 cells. Cell. Signal. 2001, 13, 23-27. [CrossRef]

42. Miura, T.; Tanno, M.; Sato, T. Mitochondrial kinase signalling pathways in myocardial protection from ischaemia/reperfusion-induced necrosis. Cardiovasc. Res. 2010, 88, 7-15. [CrossRef]

43. Wang, C.; Hu, S.M.; Xie, H.; Qiao, S.G.; Liu, H.; Liu, C.F. Role of mitochondrial ATP-sensitive potassium channel-mediated PKC- $\varepsilon$ in delayed protection against myocardial ischemia/reperfusion injury in isolated hearts of sevoflurane-preconditioned rats. Braz. J. Med. Biol. Res. Rev. Bras. Pesqui. Medicas E Biol. 2015, 48, 528-536. [CrossRef]

44. Park, J.I.; Shin, C.Y.; Lee, Y.W.; Huh, I.H.; Sohn, U.D. Endothelium-dependent Sensory Non-adrenergic Non-cholinergic Vasodilatation in Rat Thoracic Aorta: Involvement of ATP and a Role for NO. J. Pharm. Pharmacol. 2000, 52, 409-416. [CrossRef]

45. Hausenloy, D.J.; Yellon, D.M. Ischaemic conditioning and reperfusion injury. Nat. Rev. Cardiol. 2016, 13, 193-209. [CrossRef]

46. Daiber, A.; Xia, N.; Steven, S.; Oelze, M.; Hanf, A.; Kröller-Schön, S.; Münzel, T.; Li, H. New Therapeutic Implications of Endothelial Nitric Oxide Synthase (eNOS) Function/Dysfunction in Cardiovascular Disease. Int. J. Mol. Sci. 2019, 20, 187. [CrossRef]

47. Jacobson, K.A.; Jarvis, M.F.; Williams, M. Purine and Pyrimidine (P2) Receptors as Drug Targets. J. Med. Chem. 2002, 45, 4057-4093. [CrossRef]

48. Ralevic, V.; Burnstock, G. Receptors for Purines and Pyrimidines. Pharmacol. Rev. 1998, 50, 413-492.

49. Coddou, C.; Yan, Z.; Obsil, T.; Huidobro-Toro, J.P.; Stojilkovic, S.S. Activation and Regulation of Purinergic P2X Receptor Channels. Pharmacol. Rev. 2011, 63, 641-683. [CrossRef]

50. Peart, J.N.; Headrick, J.P. Adenosinergic cardioprotection: Multiple receptors, multiple pathways. Pharmacol. Ther. 2007, 114, 208-221. [CrossRef]

51. Maddock, H.L.; Broadley, K.J.; Bril, A.; Khandoudi, N. Role of endothelium in ischaemia-induced myocardial dysfunction of isolated working hearts: Cardioprotection by activation of adenosine $\mathrm{A}(2 \mathrm{~A})$ receptors. J. Auton. Pharmacol. 2001, 21, 263-271. [CrossRef]

52. Day, Y.-J.; Huang, L.; McDuffie, M.J.; Rosin, D.L.; Ye, H.; Chen, J.-F.; Schwarzschild, M.A.; Fink, J.S.; Linden, J.; Okusa, M.D. Renal protection from ischemia mediated by A2A adenosine receptors on bone marrow-derived cells. J. Clin. Investig. 2003, 112, 883-891. [CrossRef]

53. Eckle, T.; Krahn, T.; Grenz, A.; Köhler, D.; Mittelbronn, M.; Ledent, C.; Jacobson, M.A.; Osswald, H.; Thompson, L.F.; Unertl, K.; et al. Cardioprotection by ecto-5'-nucleotidase (CD73) and A2B adenosine receptors. Circulation 2007, 115, 1581-1590. [CrossRef]

54. Peart, J.; Flood, A.; Linden, J.; Matherne, G.P.; Headrick, J.P. Adenosine-mediated cardioprotection in ischemic-reperfused mouse heart. J. Cardiovasc. Pharmacol. 2002, 39, 117-129. [CrossRef]

55. Maddock, H.L.; Mocanu, M.M.; Yellon, D.M. Adenosine A(3) receptor activation protects the myocardium from reperfusion/reoxygenation injury. Am. J. Physiol. Heart Circ. Physiol. 2002, 283, H1307-H1313. [CrossRef]

56. Nanhwan, M.K.; Ling, S.; Kodakandla, M.; Nylander, S.; Ye, Y.; Birnbaum, Y. Chronic treatment with ticagrelor limits myocardial infarct size: An adenosine and cyclooxygenase-2-dependent effect. Arterioscler. Thromb. Vasc. Biol. 2014, 34, 2078-2085. [CrossRef] 
57. Yang, X.-M.; Liu, Y.; Cui, L.; Yang, X.; Liu, Y.; Tandon, N.; Kambayashi, J.; Downey, J.M.; Cohen, M.V. Platelet P2Y12 blockers confer direct postconditioning-like protection in reperfused rabbit hearts. J. Cardiovasc. Pharmacol. Ther. 2013, 18, 251-262. [CrossRef]

58. Lochner, A.; Marais, E.; Genade, S.; Huisamen, B.; du Toit, E.F.; Moolman, J.A. Protection of the ischaemic heart: Investigations into the phenomenon of ischaemic preconditioning. Cardiovasc. J. Afr. 2009, 20, 43-51.

59. Cohen, S.; Megherbi, M.; Jordheim, L.P.; Lefebvre, I.; Perigaud, C.; Dumontet, C.; Guitton, J. Simultaneous analysis of eight nucleoside triphosphates in cell lines by liquid chromatography coupled with tandem mass spectrometry. J. Chromatogr. B Analyt. Technol. Biomed. Life Sci. 2009, 877, 3831-3840. [CrossRef]

60. Canelas, A.B.; ten Pierick, A.; Ras, C.; Seifar, R.M.; van Dam, J.C.; van Gulik, W.M.; Heijnen, J.J. Quantitative evaluation of intracellular metabolite extraction techniques for yeast metabolomics. Anal. Chem. 2009, 81, 7379-7389. [CrossRef]

61. Zhang, G.; Walker, A.D.; Lin, Z.; Han, X.; Blatnik, M.; Steenwyk, R.C.; Groeber, E.A. Strategies for quantitation of endogenous adenine nucleotides in human plasma using novel ion-pair hydrophilic interaction chromatography coupled with tandem mass spectrometry. J. Chromatogr. A 2014, 1325, 129-136. [CrossRef]

62. Feliu, C.; Millart, H.; Guillemin, H.; Vautier, D.; Binet, L.; Fouley, A.; Djerada, Z. Validation of a fast UPLC-MS/MS method for quantitative analysis of opioids, cocaine, amphetamines (and their derivatives) in human whole blood. Bioanalysis 2015, 7, 2685-2700. [CrossRef]

63. Djerada, Z.; Feliu, C.; Tournois, C.; Vautier, D.; Binet, L.; Robinet, A.; Marty, H.; Gozalo, C.; Lamiable, D.; Millart, H. Validation of a fast method for quantitative analysis of elvitegravir, raltegravir, maraviroc, etravirine, tenofovir, boceprevir and 10 other antiretroviral agents in human plasma samples with a new UPLC-MS/MS technology. J. Pharm. Biomed. Anal. 2013, 86, 100-111. [CrossRef]

64. Livak, K.J.; Schmittgen, T.D. Analysis of relative gene expression data using real-time quantitative PCR and the 2(-Delta Delta C(T)) Method. Methods 2001, 25, 402-408. [CrossRef]

65. Djerada, Z.; Feliu, C.; Cazaubon, Y.; Smati, F.; Gomis, P.; Guerrot, D.; Charbit, B.; Fernandes, O.; Malinovsky, J.-M. Population Pharmacokinetic-Pharmacodynamic Modeling of Ropivacaine in Spinal Anesthesia. Clin. Pharmacokinet. 2018, 57, 1135-1147. [CrossRef]

66. Djerada, Z.; Fournet-Fayard, A.; Gozalo, C.; Lelarge, C.; Lamiable, D.; Millart, H.; Malinovsky, J.-M. Population pharmacokinetics of nefopam in elderly, with or without renal impairment, and its link to treatment response. Br. J. Clin. Pharmacol. 2014, 77, 1027-1038. [CrossRef] 